\title{
A Multivariate Filter to Estimate Potential Output and NAIRU for the Maltese Economy
}

\author{
Brian Micallef $^{1}$ \\ ${ }^{1}$ Central Bank of Malta, Valletta, Malta \\ Correspondence: Brian Micallef, Economics and Research Department, Central Bank of Malta, Valletta, \\ VLT1060, Malta. Tel: 356-2248-7922. E-mail: micallefb@centralbankmalta.org
}

Received: February 3, 2016

Accepted: February 17, $2016 \quad$ Online Published: April 25, 2016

doi:10.5539/ijef.v8n5p13

URL: http://dx.doi.org/10.5539/ijef.v8n5p13

\begin{abstract}
This paper applies a multivariate filter on a small macroeconomic model to derive estimates of Malta's potential output growth, the output gap and NAIRU. The unobservable variables are derived from a system that incorporates long-standing relationships in economic theory, such as the Phillips Curve and Okun's Law, while also allowing for hysteresis effects. Given the structural changes in the Maltese economy, with a shift over the past decade from traditional industries such as manufacturing towards higher-value added and export-oriented services, the model replaces a common variable used in the literature, capacity utilization in manufacturing, with two foreign variables, demand and imported inflation. The inclusion of foreign variables is important since Malta is one of the most open economies in the world with a high degree of import content. The model is also able to account for the high degree of volatility manifested in the time series of very small open economies. The estimates from the multivariate filter are compared with those derived from alternative approaches. Despite the negative impact from the financial crisis of 2009, by 2014 potential output growth had already surpassed the pre-crisis growth rates. The crisis had no permanent impact on NAIRU. This performance is clearly at odds with that of other European economies and bodes well for Malta's convergence process.
\end{abstract}

Keywords: potential output, output gap, NAIRU, multivariate filter, Malta

\section{Introduction}

Estimating potential output has always been a challenge for policymakers, especially in economies undergoing structural changes. The Maltese economy is a typical example. From around 4\% in the second half of the 1990s, GDP growth decelerated to around $2 \%$ per annum in the early 2000s as the economy was hit by a combination of adverse demand and supply shocks. During this period, a number of manufacturing industries were negatively affected by the liberalization policies and the dismantling of trade barriers in the run-up to EU membership in 2004. The pre-crisis recovery was driven by the diversification of the economy from traditional industries towards high value-added sectors, mostly in the services sector. The economic and financial crisis of 2009 led to a contraction in output but growth rebounded strongly in the following years such that, by end of 2014, real GDP was around $15 \%$ higher compared to early 2008. At the same time, the labour market remained resilient with unemployment declining to historical lows and rising participation rates.

This paper applies a multivariate filter proposed by Benes et al. (2010) on a small macroeconomic model to derive estimates of Malta's potential output growth, the output gap and NAIRU. Some adjustments are however necessary to tailor the model to Malta's unique characteristics. Given the structural changes of the economy, with a shift over the past decade from traditional industries such as manufacturing towards higher-value added and export-oriented services, capacity utilization in manufacturing, a commonly used variable in this literature, is replaced with two foreign variables, demand and imported inflation. The inclusion of the foreign variables is crucial since Malta is one of the most open economies in the world, with exports-to-GDP ratio of around 150\% and a high degree of import content. Finally, the model is augmented with measurement errors to account for the high degree of volatility manifested in the time series of very small open economies (Grech, 2013).

The unobserved components are estimated using the Kalman filter with Bayesian inference methods. The multivariate filter is considered a hybrid approach, blending statistical filters with long-standing relationships in economic theory, such as the Phillips Curve and Okun's Law. It also allows for hysteresis effects, a potentially interesting feature in the aftermath of a financial crisis. An advantage of this framework is that, in addition to 
potential output, the model allows for the simultaneous estimate of the output gap, NAIRU and the unemployment gap.

The estimation of these unobserved variables is important for both forecasting and policy analysis. For instance, potential output and the associated cyclical position of the economy have an effect on the conduct and evaluation of fiscal policy. Recent changes in domestic and European fiscal frameworks, such as the "Fiscal Compact", place more emphasis on the calculation of the underlying fiscal position and the specification of medium-term objectives (MTO) in structural terms. In turn, independent fiscal councils in each member states are being established to supervise domestic compliance with the new fiscal rules.

The main findings are summarized as follows. Despite the negative impact from the financial crisis of 2009, by 2014 potential output growth had already surpassed the pre-crisis growth rates and is gradually catching-up to the higher growth rates registered in the late 1990s. The output gap was broadly in balance after the crisis given the strong recovery in both actual and potential GDP growth. The crisis had no permanent impact on NAIRU, which maintained its downward trend observed over the past decade. This performance is clearly at odds with that of other European economies and bodes well for Malta's convergence process.

The rest of the paper is organized as follows. Section 2 provides a brief review of the literature on the main approaches used to estimate potential output and NAIRU. Section 3 describes the multivariate filter and the estimation methodology. Section 4 reports the empirical estimates of the permanent and cyclical components of GDP and the unemployment rate. Section 5 compares the estimates from the multivariate filter with alternative estimates for Malta and from survey data, while section 6 reports on sensitivity analysis to assess the robustness of the findings. Section 7 concludes.

\section{Literature Review}

One of the most common approaches to estimate unobservable variables such as potential output and NAIRU is the Hodrick-Prescott (HP) filter. The wide application of the HP filter is mostly due its simplicity and minimal data requirement. However, it contains several drawbacks. It suffers from poor reliability at the end of the sample, which limits its usefulness for estimating the current value of potential output. The choice of the smoothing parameter is critical but ultimately arbitrary (Note 1). It also tends to smooth structural breaks, even if these take the form of clear shifts in the level or the rate of growth of the series. Another commonly used method is the band-pass filter (Baxter \& King, 1999; Christiano \& Fitzgerald, 2003) although most of the criticism on the HP-filter applies also to these methods.

Multivariate approaches attempt to extract the trend using the information in the output series in conjunction with information contained in other variables. More generally, these techniques typically attempt to take into account empirical relationships, such as the Phillips curve and Okun's Law. Initial papers in the literature focused mainly on the relationship between output, inflation and the unemployment rate (Apel \& Jansson, 1999; Fabiani \& Mestre, 2004). More recent applications, however, extended the number of observable variables. Benes et al. (2010) estimate a multivariate filter for 12 developed economies using also data on inflation expectations and capacity utilization in manufacturing. This filter closely resembles the single-country structure of the IMF's Global Projection Model (Carabenciov et al., 2008a, b, c). Blagrave et al. (2015) extend the multivariate filter of Benes et al (2010) by introducing information from consensus forecasts.

Similar filters for small open economies introduce additional features to capture country-specific characteristics. For instance, Berger and Kempa (2014) estimate potential output and the output gap for Canada using data on interest rates and the exchange rate. In addition to the usual variables, Sramkova et al. (2010) use also FDI inflows to calculate the output gap in Slovakia. Similarly, Bokan and Ravnik (2012) extend the model by Benes et al. (2010) for Croatia by adding additional variables such as retail trade, industrial production and the current account. Benes and N'Diaye (2004) extend a similar filter for the Czech Republic using also domestic and foreign interest rates, the exchange rate and imported inflation.

In addition to these filtering techniques, there are other common methods in the literature used to estimate potential output (Note 2). The production function framework provides a comprehensive economic framework with a clear link between output and its fundamental determinants, namely total factor productivity and capital and labour inputs. In Grech and Micallef (2013), the latter is further decomposed into the main labour market components, like the working-age population, the trend participation rate, the structural unemployment rate and trend hours worked. But other decompositions or functional forms are also possible (Note 3). The production function approach is the method used by the European Commission for the calculation of the cyclically-adjusted fiscal balances for the purposes of the Stability and Convergence Reports (D'Auria et al., 2010). Another common approach to derive potential output is the one proposed by Blanchard and Quah (1989). These authors 
apply a SVAR model with long-run restrictions using data on GDP and the unemployment rate to distinguish between demand (temporary) and supply (permanent) shocks. Finally, measures of potential output can also be derived using DSGE models (Smets \& Wouters, 2003, 2007; Vetlov et al., 2011). Within this framework, the model-consistent measure of potential output is defined as the output level that would be realised in equilibrium if prices and wages were perfectly flexible.

\section{The Multivariate Filter}

The multivariate filter developed in this paper builds heavily on similar models in the literature to estimate potential output and NAIRU, most notably Benes et al. (2010). The model consists of the following 10 equations.

The Macroeconomic Model:

$$
\begin{aligned}
& Y_{t}=Y B A R_{t}+Y G A P_{t}+\epsilon^{y_{-} m e} \\
& Y B A R_{t}=Y B A R_{t-1}+G_{t} / 4-\vartheta \Delta U B A R_{t}+\varepsilon^{Y B A R} \\
& G_{t}=(1-\tau) G_{t-1}+\tau G S S_{t}+\varepsilon^{G} \\
& Y G A P_{t}=\theta_{1} Y_{G A P_{t-1}}+\theta_{2} \text { FDEM }_{t}-\theta_{3}\left(\text { PIEX }_{t-1}-P S T A R_{t-1}\right)+\varepsilon^{Y G A P} \\
& U_{t}=U B A R_{t}+U G A P_{t}+\epsilon^{u} u_{-} \\
& U B A R_{t}=U B A R_{t-1}-\omega Y G A P_{t-1}+\varepsilon^{U B A R} \\
& U G A P_{t}=\alpha_{1} U G A P_{t-1}-\alpha_{2} Y G A P_{t}+\varepsilon^{U G A P}
\end{aligned}
$$

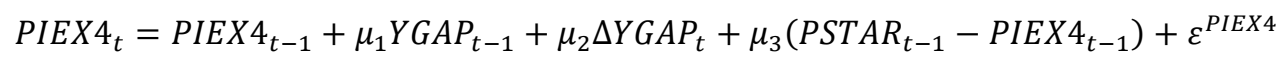

$$
\begin{aligned}
& F D E M_{t}=\rho_{\text {fdem }} F D E M_{t-1}+\varepsilon^{F D E M} \\
& \text { PSTAR }_{t}=\rho_{\text {pstar }} P S T A R_{t-1}+\varepsilon^{P S T A R}
\end{aligned}
$$

Equation (1) is an identity, defining GDP (Y) as the sum of two unobserved components, the trend component, the potential output (YBAR) and the cyclical component, the output gap (YGAP). Output refers to the natural logarithm of the seasonally-adjusted real GDP. $\epsilon^{\mathrm{y}-\mathrm{me}}$ represents the measurement error.

Equation (2) describes the stochastic behaviour of the trend component, YBAR, which follows a random walk with a time-varying drift. $\varepsilon^{\mathrm{YBAR}}$ is a shock to the level of potential output. Potential output depends on the underlying trend growth $(\mathrm{G})$ and on changes in NAIRU. Changes in NAIRU may cause potential growth to differ from $\mathrm{G}$, where the first difference, $\triangle \mathrm{UBAR}$, captures the impact of changes in the equilibrium level of unemployment on the growth rate of potential output, with $\vartheta$ being the share of labour in GDP.

Equation (3) describes the time-varying drift in the growth rate of potential output. In the long run, the growth rate of potential output is equal to its steady state growth rate, GSS. In the short to medium term, however, it can diverge from this steady state growth rate following a shock to the growth rate of potential output, $\varepsilon^{\mathrm{G}}$. The parameter $\tau$ determines the speed with which the economy returns to its steady state growth rate after a shock.

Equation (4) describes the dynamics of the output gap which is assumed to depend on its own lagged value, the cyclical component of foreign demand and the deviation of domestic prices from foreign prices. The latter capture the importance of external price competitiveness for a small and open economy like Malta and is also necessary given the absence of monetary policy from the model. The negative effect on demand from losses in price competitiveness is consistent with a broad range of monetary regimes. For instance, in an inflation-targeting regime, higher inflation will be met by a tightening of monetary policy, which will reduce the output gap whereas, in a fixed exchange rate regime, relatively high inflation will lead to an appreciation of the real exchange rate, eventually dampening excess demand.

Equations (5) to (7) constitute the labour market block. Equation (5) is an identity, defining the seasonally-adjusted unemployment rate as the sum of the trend component (UBAR) and the cyclical component (UGAP). $\epsilon^{\mathrm{u}}{ }^{\mathrm{me}}$ represents the measurement error. The trend component refers to the NAIRU. Equation (6) describes the dynamics of NAIRU, which is modeled as a random walk stochastic process. The inclusion of the output gap in NAIRU represents a partial hysteresis effect from economy-wide demand fluctuations. Equation (7) specifies a dynamic Okun's Law, linking the unemployment gap to the output gap.

Equation (8) describes a Phillips Curve relationship to explain the dynamics of core inflation, defined as HICP inflation excluding energy, food, alcohol and tobacco. The lagged term captures inertia and rigidity in the price adjustment mechanism and, in the absence of a suitable variable to capture forward-looking inflation expectations, also represents an adaptive process in forming expectations. The restriction of one implies the 
absence of a long-run tradeoff between the nominal and the real side of the economy. Core inflation is also influenced by the lagged level and the change in the output gap. The former incorporates the standard short-run tradeoff between economic activity and inflation, while the latter reflects certain rigidities in the adjustment of the economy. The last term captures the impact of foreign prices on domestic inflation, which is an important channel in a small and open economy with a high degree of import content.

Equations (9) and (10) model the two foreign variables - demand (FDEM) and prices (PSTAR) - as a first-order autoregressive process. The error terms in all equations are assumed to follow standard assumptions, i.e. are identically and independently normally distributed and uncorrelated.

\section{Estimation and Empirical Results}

\subsection{Estimation}

The model is estimated using Bayesian inference techniques on quarterly data from 1999Q1 to 2015Q2 using five observables: real GDP, year-on-year core HICP inflation, the unemployment rate, the cyclical component of foreign demand and core HICP inflation in the euro area (Note 4). As explained in Carabenciov et al (2008a, b, c), an important advantage of this methodology is the use of prior information that restricts parameters to remain within economically sensible regions. This is especially important in the case of Malta where the sample size is relatively small and the data could be uninformative about several parameters.

The share of labour in GDP ( $\vartheta$ ) was calibrated ex-ante at 0.58 , equivalent to the share of wages in Gross Value Added adjusted for the share of self-employed. In line with similar studies, the standard deviation of NAIRU was calibrated at 0.1, which according to Gordon (1997), 'results in NAIRU series that exhibits substantial movements but just avoids sharp quarter-to-quarter zig-zags' (Note 5). The variance of the measurement errors was calibrated to correspond to around $15 \%$ of the variance in GDP growth and the change in the unemployment rate.

The choice of priors relied heavily on similar studies in the literature, in particular to Carabenciov et al. (2008a, b, c) and Benes et al. (2010). The choice of prior distributions reflects restrictions on the parameters, such as non-negativity or interval restrictions. Beta distribution was used for parameters constrained on the unit interval, while the gamma distribution was chosen for parameters in R+. Inverse gamma distribution was chosen for the standard deviation of the shock processes.

\subsection{Empirical Results}

Appendix A reports the posterior means and the 68 percent confidence intervals of the posterior distribution computed with the Metropolis Hastings algorithm. The results are based on two distinct chains of 500,000 draws each, after discarding the first $20 \%$ of the draws. The average acceptance rate is around $22 \%$ for both chains, which is broadly in line with the optimal acceptance rate.

The posterior mean of the parameter $\tau$ is estimated at 0.11 which implies that the impact of shocks on the growth rate of potential output is very persistent. This result is in line with the findings in the literature. In the output gap equation, the weight of the lagged output gap parameter is estimated at 0.48 , implying a moderately persistent output gap. The lagged foreign demand indicator is estimated at 0.18 , which although lower than the prior mean, confirms the importance of foreign demand in shaping the dynamics of the domestic output gap. The weight of the price competitive term is around 0.09 , broadly in line with the prior. Turning to Okun's Law equation, the lagged impact of the unemployment gap is estimated at around 0.66 , implying a moderately more persistent unemployment gap compared to the output gap. The elasticity of the unemployment gap to the lagged output gap is estimated at around 0.10, in line with estimates for Okun's Law in Malta presented in Micallef (2013b). The impact of the demand fluctuations on NAIRU is estimated at 0.03 , lower than the prior, suggesting weak hysteresis effects in Malta. In the Phillip's Curve equation, speed-limit effects have a higher impact on domestic inflation compared to the level of the output gap, suggesting that adjustment rigidities can potentially play an important role in shaping domestic price pressures. While lower than the prior, the impact of foreign inflation is also relatively stronger than the level of the output gap, a not surprising result for a small and open economy with a high degree of import content. Finally, the steady-state growth rate is estimated at $2.6 \%$, above the prior of $2.5 \%$. 

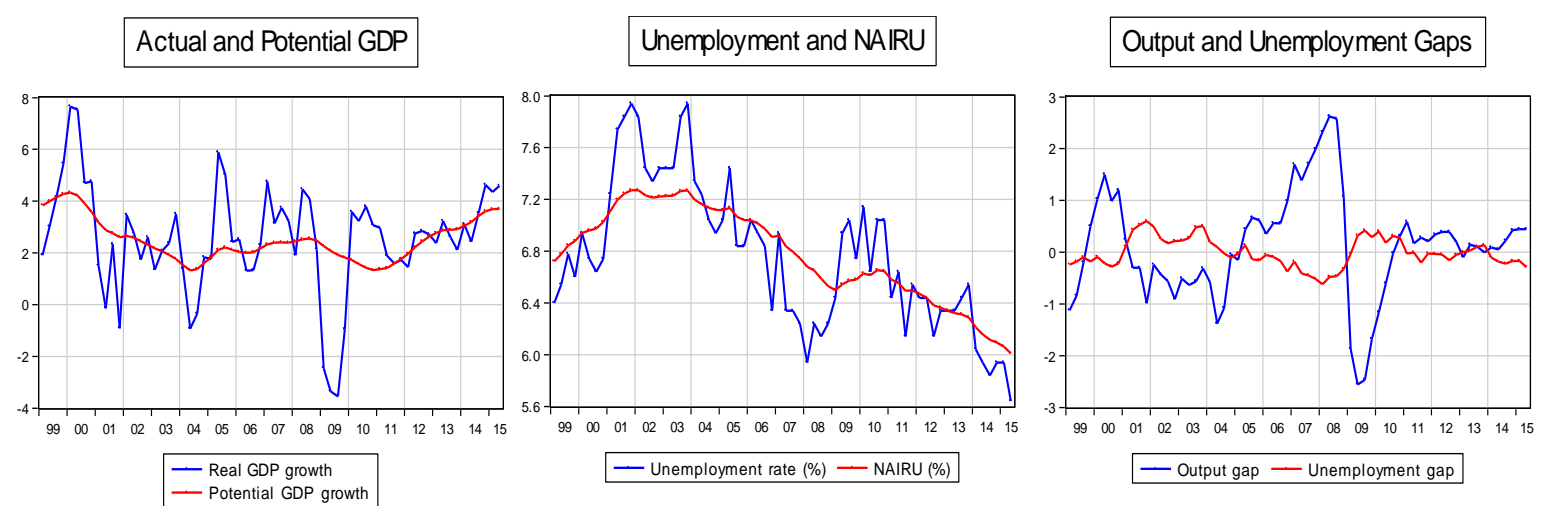

Figure 1. Trend and cyclical components of GDP and unemployment

Source: Author's calculations.

Figure 1 plots the main results. As expected, the estimated potential GDP growth rate is smoother than the actual GDP growth rate, which was quite volatile in the period under consideration, ranging from $6.4 \%$ in 2000 to $-2.6 \%$ in 2009. According to the multivariate filter, potential GDP growth stood around $4 \%$ in 2000 but declined to below $2 \%$ by 2004 . Potential GDP growth increased gradually and peaked at around $2.5 \%$ in 2008 . The financial crisis had a negative impact on potential GDP growth but this recovered strongly such that, by 2014, it had exceeded the pre-crisis growth rates. The positive momentum was maintained in the first half of 2015 .

Developments in NAIRU were broadly positive over the last decade, with a trend decline from above $7 \%$ in the early 2000 s to around $6.1 \%$ in 2014 . Contrary to the experience in other euro area economies, the crisis had no permanent impact on NAIRU (Note 6).

The output gap was mostly in negative territory in the early 2000s, reaching a trough in 2004. It then turned positive in 2007 and peaked at around $2.5 \%$ in 2008. However, the onset of the 2009 recession led to a sharp contraction in output growth, with the output gap turning sharply negative again. The speed of the recovery in Malta's output growth after the crisis implied a rapid closure of the output gap. This is clearly at odds with the experience in other European economies where estimates of the output gap remain in negative territory six years after the start of the crisis.

The unemployment gap captures slack in the domestic labour market and broadly mirrors developments in the output gap. This gap has been broadly positive in the early 2000s mainly as a result of the restructuring in the manufacturing industry, especially the downsizing of the relatively labour intensive textile and clothing sectors. The subsequent decline in the unemployment before the onset of the crisis was the result of buoyant economic activity and the restructuring of the economic base towards higher value-added activities, mostly services oriented. As a result, the unemployment gap turned negative in 2007 and 2008. The increase in the unemployment rate during the recession of 2009 , with the manufacturing and tourism industries being the worst hit, led the unemployment gap to turn positive again. As the impact of the recession was less severe in Malta compared to other euro area countries, the rise in the unemployment rate started to be reversed already by 2010 . As a result, the build-up of the positive unemployment gap during the recession was short-lived and the cyclical component of the unemployment rate was broadly in balance between 2011 and 2013.

While the two cyclical indicators - the output and unemployment gaps - tend to move in synch in opposite directions, the output gap is much more volatile than the unemployment gap. This is to a large extent influenced by the fact that over the past decade, the volatility of output was much pronounced than that of the unemployment rate, which, despite the large shocks hitting the economy over this period, fluctuated between the relatively narrow range of $5.5 \%$ to $8 \%$.

As with most econometric models, the results are naturally conditioned on the underlying system of equations. To cross-check these estimates, the next section compares the estimates from the multivariate filter with those obtained from alternative methodologies.

\section{Comparison with Alternative Approaches}

Given that the estimates from the multivariate filter are unobservable variables, there is no formal criterion of fit. Figure 2 compares the estimates of the annual growth rate in potential output, the output gap and NAIRU with 
those obtained from the HP-filter using two different smoothing parameters. The first is 1600, proposed by Kydland and Prescott (1990) and the other is 7680, proposed by Almeida (2009) for Portugal, which is also a small and open economy in a monetary union. To avoid the end-of-sample problem, the GDP and unemployment series were extended until 2018 using the European Commission's Autumn 2015 economic forecasts.

The annual growth rate of potential output is more pronounced compared to those obtained from univariate filters. The dynamics of potential output growth from the multivariate filter are in fact close to the production function approach, described in Micallef and Grech (2013) and the estimates of the European Commission in its Autumn 2015 Economic Projections. The latter two estimates are only available on an annual basis and are therefore not shown in Figure 2. The estimates from the HP-filter capture the trend decline in potential growth in the early 2000s but not the pre-crisis upswing. All estimates, however, point to a strong recovery in potential output growth after the crisis, with the growth rate in 2014 ranging from $3.2 \%$ to $3.7 \%$.

The estimates of the output gap from the multivariate filter are broadly similar to those obtained from the HP-filter but are less volatile. This is due to the inclusion of the measurement error in the multivariate filter (equation 1) that is intended specifically to cater for the noise and the high degree of volatility in the data. A closer inspection of the measurement errors suggest that they have become less volatile over time, possibly reflecting improvements in the data collection process by the statistical authority following the introduction of quarterly national accounts statistics in 2000 (Note 7).

Finally, the three alternative estimates point to broadly similar developments in NAIRU with a slight difference observed only during the recession. According to the multivariate filter, the recession led to a slight, though temporary increase in NAIRU (owing to the partial hysteresis effects) whereas the HP filtered measures maintained their downward trend. Estimates of NAIRU for 2014 are broadly similar across the different approaches. The similarity of the NAIRU estimates is in turn reflected in very similar dynamics of the unemployment gap although the measure from the multivariate filter is relatively smoother due to the inclusion of measurement error.
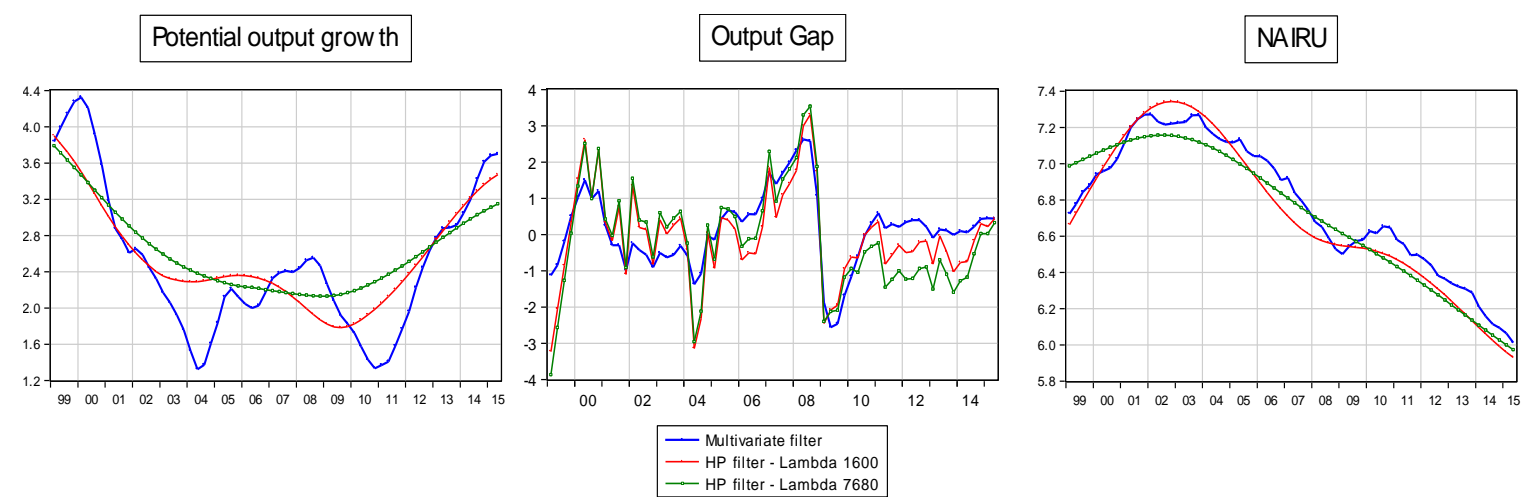

Figure 2. Comparison with HP-filtered estimates

Source: Author's calculations.

\section{Sensitivity Analysis}

Due to their unobservable nature, estimates of potential output and NAIRU are surrounded by a high degree of uncertainty. In the context of a multivariate filter, the dynamics of the unobservable variables could be very sensitive to the priors of the shock processes, especially the ones for the stochastic processes of trend potential output growth ( $\varepsilon^{G}$ in equation 3 ) and NAIRU ( $\varepsilon^{\text {UBAR }}$ in equation 6 ). To assess the sensitivity of the results to these priors, these were changed in several ways and the model re-estimated in each of them.

Seven different cases were considered. The prior mean for the disturbance $\varepsilon^{\mathrm{G}}$ was set at 0.4 and 0.75 , respectively. In two separate cases, the prior mean for the disturbance $\varepsilon^{\mathrm{UBAR}}$ was set at 0.07 and 0.13 , respectively. In another version, the prior on the parameter $\tau$ was increased from 0.10 to 0.25 , thereby reducing the speed with which the economy returns to the steady state after a shock. Another version eliminated the hysteresis parameter in equation 6 . Finally, a version of the model was estimated by reducing the measurement errors by half.

Figure 3 displays the range of estimates for potential output growth, the output gap and NAIRU to the different 
specifications of the model. Despite some uncertainty surrounding point estimates, the sensitivity analysis broadly confirm the findings and main conclusions of the previous sections. In particular, potential output growth has recovered strongly after the 2009 crisis and has exceeded the pre-crisis growth rates achieved in the 2000s. All model variants confirm the dynamics of the output gap, with most variation driven by the reduction in the measurement errors. Finally, NAIRU has been trending downwards for the large part of the last decade and the sensitivity analysis confirm that the 2009 recession had no permanent effect on the structural unemployment rate.

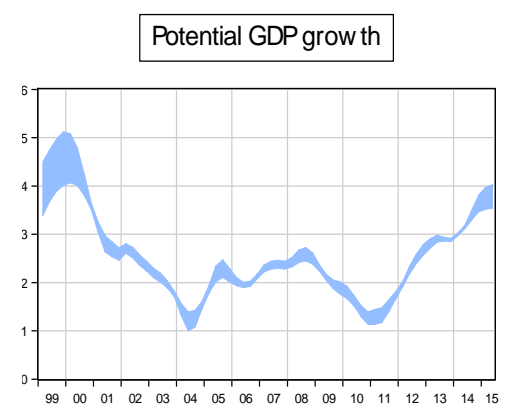

Source: Author's calculations.
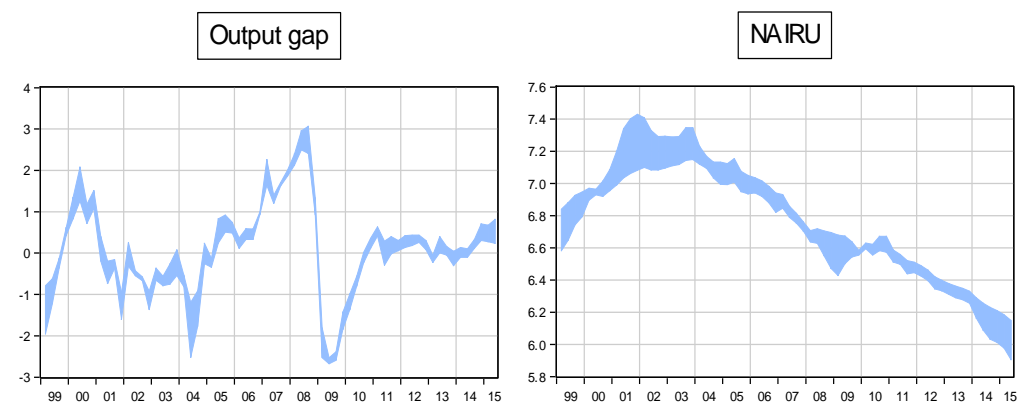

Figure 3. Sensitivity analysis

Note. The range plots the maximum and minimum values from the different model specifications.

\section{Concluding Remarks}

This paper applies a multivariate filter on a small macroeconomic model to derive estimates of Malta's potential output growth, the output gap and NAIRU. These unobservable variables were derived from a system that accounts for the interactions between output, core inflation, unemployment and two foreign variables, reflecting the structural characteristics of Malta as a small and open economy. The model is also augmented with measurement error to account for the high degree of volatility manifested in the time series of very small open economies. Given the uncertainty surrounding these latent variables, the estimates from the multivariate filter were compared with HP-filtered estimates with different smoothing parameters, as well as those derived from a production function approach.

Several interesting and policy relevant results are worth highlighting. First, the multivariate filter confirms the significant changes in Malta's potential output growth and NAIRU over the past decade. In particular, the 2009 recession had an adverse impact on potential output growth but this has recovered strongly after the crisis and has even exceeded the pre-crisis growth rates. NAIRU has generally been on a downward trend over the past decade and various estimates suggest that the crisis had no permanent effect on the structural unemployment rate. This is clearly at odds with the experience of other European economies and bodes well for Malta's convergence process.

\section{Acknowledgments}

The author is grateful to Valentina Aprigliano and Aaron G Grech for helpful comments and suggestions. Any errors, as well as the views expressed in this article, are the author's sole responsibility. The views expressed in this paper are those of the author and should not be interpreted as reflecting the views of the Central Bank of Malta.

\section{References}

Almeida, V. (2009). Bayesian estimation of a DSGE model for the Portuguese economy. Banco de Portugal Working Paper No. 14, 2009. Retrieved from http://www.bportugal.pt/en-US/BdP\%20Publications\%20Research/WP200914.pdf

Apel, M., \& Jansson, P. (1999). System estimates of potential output and the NAIRU. Empirical Economics, 24(3), 373-388. http://dx.doi.org/10.1007/s001810050061

Baxter, M., \& King, R. G. (1999). Measuring business cycles: Approximate band-pass filters for economic time $\begin{array}{lllll}\text { series. The Review of Economics and Statistics, 81(4), 575-593. } & \text {. }\end{array}$ http://dx.doi.org/10.1162/003465399558454 
Benes, J., \& N'Diaye, P. (2004). A Multivariate filter for measuring potential output and the NAIRU: Application to the Czech Republic. IMF Working Paper WP/04/45. Retrieved from https://www.imf.org/external/pubs/ft/wp/2004/wp0445.pdf

Benes, J., Clinton, K., Garcai-Saltos, R., Johnson, M., Laxton, D., Manchev, P., \& Matheson, T. (2010). Estimating potential output with a multivariate filter. IMF Working Paper WP/10/285. Retrieved from https://www.imf.org/external/pubs/ft/wp/2010/wp10285.pdf

Berger, T., \& Kempa, B. (2014). Time-varying equilibrium rates in small open economies: Evidence for Canada. Journal of Macroeconomics, 39(PA), 203-214. http://dx.doi.org/10.1016/j.macro.2013.12.002

Blagrave, P., Garcia-Saltos, R., Laxton, D., \& Zhang, F. (2015). A simple multivariate filter for estimating potential output. IMF Working Paper No.15/79. Retrieved from https://www.imf.org/external/pubs/ft/wp/2015/wp1579.pdf

Blanchard, O. J., \& Quah, D. (1988). The dynamic effect of aggregate demand and supply disturbances. American Economic Review, 79(4), 655-673. Retrieved from http://www.jstor.org/stable/1827924

Bokan, N., \& Ravnik, R. (2012). Estimating potential output in the Republic of Croatia using a multivariate filter. Croatian National Bank Working Paper W-35. Retrieved from http://www.hnb.hr/publikac/istrazivanja/w-035.pdf

Carabenciov, I., Ermolaev, I., Freedman, C., Juillard, M., Kamenik, O., Korshunov, D., \& Laxton, D. (2008a). A Small Quarterly Projection Model of the US Economy. IMF Working Paper WP/08/278. Retrieved from https://www.imf.org/external/pubs/ft/wp/2008/wp08278.pdf

Carabenciov, I., Ermolaev, I., Freedman, C., Juillard, M., Kamenik, O., Korshunov, D., Laxton, D., \& Laxton, J. (2008b). A Small Multi-Country Global Projection Model. IMF Working Paper WP/08/279. Retrieved from https://www.imf.org/external/pubs/ft/wp/2008/wp08279.pdf

Carabenciov, I., Ermolaev, I., Freedman, C., Juillard, M., Kamenik, O., Korshunov, D., Laxton, D., \& Laxton, J. (2008c). A Small Multi-Country Global Projection Model with Financial-Real Linkages and Oil Prices. IMF Working Paper WP/08/280. from https://www.imf.org/external/pubs/ft/wp/2008/wp08280.pdf

Centeno, M., Maria, R. J., \& Novo, A. (2009). Unemployment: Supply, demand and institutions. In The Portugese Economy in the Context of Economic, Financial and Monetary Integration, Banco de Portugal Publication.

Christiano, L. J., \& Fitzgerald, T. J. (2003). The band pass filter. International Economic Review, 44(2). Retrieved from http://www.jstor.org/stable/3663474

D’Auria, F., Denis, C., Havik, K., McMorrow, K., Planas, C., Raciborski, W., \& Rossi, A. (2010). The production function methodology for calculating potential growth rates \& output gaps. European Economy $\begin{array}{llll}\text { Economic } & \text { Papers } & \text { Retrieved } & \text { from }\end{array}$ http://ec.europa.eu/economy_finance/publications/economic_paper/2014/pdf/ecp535_en.pdf

Dieppe, A., Gonzalez Pandiella, A., \& Willman, A. (2011). The ECB's New Multi-Country Model for the euro area: NMCM - simulation with rational expectations. ECB Working Paper 1315. Retrieved from https://www.ecb.europa.eu/pub/pdf/scpwps/ecbwp1315.pdf?c66ab0c39d33bbe6f20f14fe5e89db54

Fabiani, S., \& Mestre, R. (2004). A system approach for measuring the euro area NAIRU. Empirical Economics, 29, 311-341. http://dx.doi.org/10.1007/s00181-003-0170-8

Gordon, R. (1997). The time-varying NAIRU and its implications for economic policy. The Journal of Economic Perspectives, 11(1), 11-32. Retrieved from http://www.jstor.org/stable/2138249

Grech, A. G. (2013). Adapting the Hodrick-Prescott filter for very small open economies. International Journal of Economics and Finance, 5(8). http://dx.doi.org/10.5539/ijef.v5n8p39

Grech, A. G., \& Micallef, B. (2013). Assessing the supply side of the Maltese economy using a production function approach. Central Bank of Malta Quarterly Review, 4.

Hodrick, R., \& Prescott, E. C. (1997). Post-war U.S. business cycles: An empirical investigation. Journal of Money, Credit and Banking, 29, 1-16. http://dx.doi.org/10.2307/2953682

Johannsson, A, Guillemette, Y., Murtin, F., Turner, D., Nicoletti, G., Maisonneuve, C., Bagnoli, P., Bousquet, G., \& Spinelli, F. (2012). Long-term growth scenarios. OECD Economics Department Working Paper 1000. 
Retrieved

from http://www.oecd.org/officialdocuments/publicdisplaydocumentpdf/?cote=ECO/WKP(2012)77\&docLangua ge $=\mathrm{En}$

Konuki, T. (2008). Estimating potential output and the output gap in Slovakia. IMF Working Paper WP/08/275. Retrieved from https://www.imf.org/external/pubs/ft/wp/2008/wp08275.pdf

Micallef, B. (2013a). Labour market resilience in Malta. Central Bank of Malta Quarterly Review, 1.

Micallef, B. (2013b). Estimating Okun's Law for Malta. Central Bank of Malta Quarterly Review, 3.

Mishkin, F. (2007). Estimating potential output. Speech delivered at the Conference on Price Measurement for Monetary Policy, FRB of Dallas, 24 May 2007. Retrieved from http://www.federalreserve.gov/newsevents/speech/mishkin20070524a.htm

Nemec, D., \& Vasicek, O. (2007). Alternative estimates of NAIRU for the Czech Economy: implications for economic growth and stability. Masaryk University Brno, 2007. Retrieved from http://www.muni.cz/research/publications/779372

Smets, F., \& Wouters, R. (2003). An estimated dynamic stochastic general equilibrium model of the euro area. Journal of the European Economic Association, 1123-1175. http://dx.doi.org/10.1162/154247603770383415

Smets, F., \& Wouters, R. (2007). Shocks and frictions in US business cycles: A bayesian DSGE approach. American Economic Review, 97(3), 586-606. http://dx.doi.org/10.1257/aer.97.3.586

Sramkova, L., Kobilicova, M., \& Krajcir, A. (2010). Output gap and NAIRU estimates within state-space framework: An application to Slovakia. Financial Policy Institute, The Ministry of Finance of the Slovak Republic, Economic Analysis 16.

Sturod, M., \& Hagelund, K. (2012). Norges Bank's output gap estimates. Norges Bank Staff Memo 08/2012. Retrieved

from http://www.norges-bank.no/Upload/Publikasjoner/Staff\%20Memo/2012/Staff_Memo_1208.pdf

Vetlov, I., Hledik, T., Jonsson, M., Kucsera, H., \& Pisani, M. (2011). Potential output in DSGE models. ECB Working Paper $1351 . \quad$ Retrieved https://www.ecb.europa.eu/pub/pdf/scpwps/ecbwp1351.pdf?2cfcf06dca35069984374de500a48a11

\section{Notes}

Note 1. Kydland and Prescott (1990) proposed a value of 1600 for quarterly data, which has since become an international standard. Other small economies, however, have found that different values produce more reasonable business cycles for their specific economies. See, for instance, Sturod and Hagelund (2012) and Almedia (2009).

Note 2. See Mishkin (2007) for a non-technical exposition of these approaches.

Note 3. For example, the OECD uses a Cobb-Douglas production function with physical capital, trend employment, human capital and a measure of labour efficiency (Johannsson et al., 2013), whereas ECB estimates using the New Multi Country Model are based on a CES production function with labour, physical capital and exogenous factor-augmenting technology (Dieppe et al., 2011).

Note 4. Foreign demand is constructed using import-weights of Malta's main trading partners. The cyclical component was HP-filtered with a smoothing parameter of 1600 . The series was extended by three years to mitigate the end-of-sample bias inherent in the filter.

Note 5. Some studies opt to fix this standard deviation ex-ante at an adequate value, different from zero (Centeno et al., 2009).

Note 6. See Micallef (2013a) for an analysis of the main factors underpinning the resilience of the domestic labour market after the crisis.

Note 7. For instance, the standard deviation of the measurement errors, which follow a white noise process, declined from 0.5 in the first half of the sample to 0.3 in the latter half. 


\section{Appendix A}

\section{Estimated parameters and shocks}

\begin{tabular}{|c|c|c|c|c|c|c|}
\hline & \multirow[b]{2}{*}{ Prior Distribution } & \multirow[b]{2}{*}{ Prior Mean } & \multirow[b]{2}{*}{ Prior St.Dev. } & \multirow[b]{2}{*}{ Posterior Mean } & \multicolumn{2}{|c|}{ Posterior 68\% HPD interva } \\
\hline & & & & & LL & $\mathrm{UL}$ \\
\hline \multicolumn{7}{|c|}{ Parameters } \\
\hline$\tau$ & beta & 0.10 & 0.05 & 0.11 & 0.05 & 0.14 \\
\hline$\theta_{1}$ & beta & 0.70 & 0.10 & 0.48 & 0.40 & 0.58 \\
\hline$\theta_{2}$ & gamma & 0.35 & 0.10 & 0.18 & 0.14 & 0.21 \\
\hline$\theta_{3}$ & gamma & 0.10 & 0.05 & 0.09 & 0.04 & 0.12 \\
\hline$\omega$ & gamma & 0.05 & 0.02 & 0.03 & 0.02 & 0.04 \\
\hline$\alpha_{1}$ & beta & 0.70 & 0.10 & 0.66 & 0.58 & 0.77 \\
\hline$\alpha_{2}$ & gamma & 0.15 & 0.05 & 0.10 & 0.07 & 0.11 \\
\hline$\lambda_{1}$ & gamma & 0.15 & 0.10 & 0.12 & 0.05 & 0.17 \\
\hline$\lambda_{2}$ & gamma & 0.15 & 0.10 & 0.17 & 0.04 & 0.22 \\
\hline$\Lambda_{3}$ & gamma & 0.20 & 0.10 & 0.15 & 0.10 & 0.19 \\
\hline$\rho_{\text {FDEM }}$ & beta & 0.70 & 0.10 & 0.81 & 0.77 & 0.86 \\
\hline$\rho_{\text {PSTAR }}$ & beta & 0.70 & 0.10 & 0.87 & 0.83 & 0.91 \\
\hline GSS & normal & 2.50 & 0.50 & 2.60 & 2.23 & 3.00 \\
\hline \multicolumn{7}{|c|}{ Standard deviation of shocks } \\
\hline$\varepsilon^{\mathrm{YBAR}}$ & inv_gamma & 0.35 & $\inf$ & 0.43 & 0.18 & 0.60 \\
\hline$\varepsilon^{\mathrm{G}}$ & inv_gamma & 0.65 & $\inf$ & 0.48 & 0.22 & 0.57 \\
\hline$\varepsilon^{\mathrm{YGAP}}$ & inv_gamma & 0.75 & inf & 0.45 & 0.28 & 0.56 \\
\hline$\varepsilon^{\mathrm{UGAP}}$ & inv_gamma & 0.50 & inf & 0.20 & 0.16 & 0.23 \\
\hline$\varepsilon^{\Pi}$ & inv_gamma & 0.75 & $\inf$ & 0.77 & 0.69 & 0.82 \\
\hline$\varepsilon^{\mathrm{FDEM}}$ & inv_gamma & 0.75 & $\inf$ & 1.62 & 1.46 & 1.73 \\
\hline$\varepsilon^{\mathrm{PSTAR}}$ & inv_gamma & 0.75 & inf & 0.19 & 0.17 & 0.21 \\
\hline
\end{tabular}

Source: Author's calculations.

\section{Copyrights}

Copyright for this article is retained by the author(s), with first publication rights granted to the journal.

This is an open-access article distributed under the terms and conditions of the Creative Commons Attribution license (http://creativecommons.org/licenses/by/3.0/). 